Vladimir Radivojević

Ministry of Defence Republic of Serbia,

Regional Centre Niš

Tanja Stanišić ${ }^{2}$

University of Kragujevac,

Faculty of Hotel Management and Tourism in Vrnjačka Banja

Bojan Krstić ${ }^{3}$

University of Niš,

Faculty of Economics
ORIGINAL SCIENTIFIC ARTICLE doi:10.5937/ekonomika1802001R

Received January, 17, 2018

Accepted: March, 01, 2018

\title{
SUSTAINABILITY OF THE STATE AID CONTROL SYSTEM IN SERBIA
}

\begin{abstract}
The category of state aid and the state aid control system as a pre-accession obligation of Serbia in the process of integration into the European Union and as a subsystem of competition protection policy are gaining actuality and importance in Serbia starting from 2010, with the beginning of the implementation of the Law on State Aid Control. The aim of the paper is to examine the sustainability of the system of state aid control in Serbia eight years after the beginning of the implementation of the law. In this paper, through a comparative analysis of the way of functioning, legal regulation and state aid granted in the European Union and Serbia, the advantages and disadvantages of the national state aid control system are highlighted.
\end{abstract}

Key words: state aid, Serbia, European Union

JEL classification: H250, H500

\section{ОДРЖИВОСТ СИСТЕМА КОНТРОЛЕ ДРЖАВНЕ ПОМОЋИ У СРБИЈИ}

\begin{abstract}
Apstrakt
Категорија државне помоћи и систем контроле државне помоћи као предприступна обавеза Србије у процесу интегращије у Европску унију и као подсистем политике застуте конкурениије, добијају на актулености и значају у Србији почев од 2010. године, са почетком примене Закона о контроли државне помоћи. Циљ рада је сагледавање одрживости система конторле државне помоћи у Србији осам година након почетка примене закона. У раду се, кроз компаративну анализу начина функционисана, правне регулисаности и додељене државне помоћи у Европској унији и Србији указује на предности и недостатке националног система контроле државне помоћи.
\end{abstract}

Кључне речи: државна помоћ, Србија, Европска унија

\footnotetext{
${ }^{1}$ vladimir.radivojevic@ymail.com

2 tanja.stanisic@kg.ac.rs

33 bojan.krstic@eknfak.ni.ac.rs
} 


\section{Introduction}

State aid is still a relatively new category in the domestic scientific and professional public. Namely, while there is a long history of developing a state aid control system at the level of the European Union (EU), state aid has been gaining importance in Serbia since 2010, with the adoption and the beginning of the application of the Law on State Aid Control. The establishment of a state aid control system is important pre-accession obligation of Serbia in the process of the EU integration.

State aid is one of the forms of implementing the interventionist policy of the state, but this institute can not be identified with the much broader concept of state interventionism. Motivated by a broad spectrum of goals, the state can use different measures to intervene in the economy and help enterprises, sectors and regions. A state can intervene on the market in three ways. One of the ways is financial support to economic entities realized through direct transfers to enterprises, investment, lowinterest loans, tax exemptions. The second way is related to the establishment of rules and regulations by the state, or its regulatory policy. The third method relates to the direct provision of goods by the state, such as infrastructure and other public goods. Only the first form of state intervention in the form of financial assistance to economic entities is considered as state aid.

The concept of state aid is considered in the paper through several steps. The first, the concept of state aid, basic categories and instruments of state aid allocation, the basic stages in the development of the state aid control system, as well as the link between the state aid control and the competition protection policy are described. The way of functioning of the system of state aid control in the EU, as the most efficient existing system, is considered, and the achieved results and perspectives of the further development of the state aid control system in Serbia are examined. Finally, an overview of the data on state aid granted in the European Union and Serbia is given.

\section{Theoretical concept of state aid}

The concept of state aid is interpreted in different ways. Interpretations are ranging in practice from those wider, according to which the state aid is each financial advantage of the beneficiaries receiving aid, to the narrower, according to which state aid is any measure that strengthens the competitive position of the recipient of aid and distorts competition. The granting of state aid implies that the state, in order to encourage appropriate economic activity, is beneficial, i.e. it places certain economic entities in a privileged position (Kesner-Škreb, 2003, p. 158). State aid is, therefore, a form of selective state intervention by which beneficiaries are favoured in relation to the competitors. State aid has the ability to distort markets and undermine competition (Kassim \& Lyons, 2013, p. 2). The control of state aid is aimed to ensure equal conditions of business for all economic entities (Krstić \& Stanišić, 2013). Hence, the control of state aid is an integral part, that is, the subsystem of competition policy.

State aid may be granted for the various purposes, and the main reason for its use is the correction of market failure (Podsiado, 2016, p. 388). The basic forms of state aid 
are horizontal, regional and sectoral (Stojanović \& Stanišić, 2015). Thereby, horizontal state aid is intended for all enterprises in an economy, not for selected and predefined sectors and regions. Horizontal state aid is focused on research and development, environmental protection, assistance to small and medium-sized enterprises, training, culture and is considered a state aid that has the least negative impact on the conditions of competition in the market. Regional state aid is allocated with the aim of stimulating the economic development of underdeveloped and less developed regions. Sectoral state aid is intended for predetermined, or well-known entities in particular sectors or sectors. Due to this highly selective character, sectoral state aid also carries the greatest risk of distorting competition on the market (Stojanović et al., 2014, p. 90).

State aid can be realized in the form of various instruments. It does not only include subsidies, as the most well-known and most often used instrument for granting state aid, but also guarantees, various types of tax relief, loans under more favorable market conditions, purchase by state or sale of state property under conditions more favorable than market ones. Because of the possibility that state aid disturb competition in the market, it is necessary to control its allocation. In addition, from a global point of view, different countries and institutions have different logic of access to state aid control. For example, for the United States of America, the lack of a state aid control system is characterized. At the EU level, this system is in constant development and is becoming more and more restrictive. Requirements for the existence of a functional state aid control system are not only valid for the existing EU Member States, but have been extended to potential members.

\section{Development of the state aid control system in the EU and Serbia}

State aid control is one of the specific aspects of the EU competition law (Stojanović et al., 2013, p. 166). The central objective of the European Union rules on state aid is to prevent competition in the internal market (Jansen, 2016, p. 575). State aid control is one of the instruments of competition policy and state aid control plays a fundamental role in defending and strengthening the single market (Bartniczak, 2016, p. 18). In addition, the need for a common competition policy and state aid control came at the beginning of realizing ideas about the community. By establishing the European Coal and Steel Community in 1951, it becomes clear that it is unjustifiable for Member States to provide priority to these sectors through various types of subsidies and state aid. This institutional experiment quickly pointed to the need to regulate other sectors of the economy (Stojanović, 2003, p. 53). Thus, in 1957, the Treaty establishing the European Economic Community was signed in Rome, which established the rules on the control of state aid in Articles 87 and 88. The rules on the control of state aid at the EU level are now regulated by the Treaty on the Functioning of the European Union. State aid is regulated by Articles 107 and 108 of this Treaty. The prohibition of state aid is confirmed by Article 107(1). Exemption from the fundamental principle of prohibition is regulated by Articles 107(2) and 107(3) (Consolidated versions of the Treaty on the Functioning of the European Union, p. 91). The absolute right of the European Commission (EC) to regulate state aid is laid down in Article 108 (Blauberger, 2008). 
Therefore, the authority responsible for the implementation of the state aid control system at the European Union level is the European Commission (Stojanović \& Stanišić, 2014, p. 88). The European Commission is responsible for monitoring the European market to ensure that competition between undertakings is free and fair (Tasan-Kok et al., 2013). The focus of state aid control is the behaviour of Member States (Blauberger, 2011, p. 28). The EU Member State must every state aid plan reports to the commission. Any unreported state aid will be considered as illegal. The responsibility of the European Commission is to examine the justification of these plans and make a decision. After completing the procedure for examining the justification of state aid, the European Commission can essentially make two types of decisions, positive and negative. The decision can be also conditional. This implies that specific state aid can be considered as justified and that the European Commission can change its decision to a positive one only if a Member State fulfils certain additional requirements. Despite the satisfactory efficiency that has been confirmed in practice, the European Commission's operation and the EU state aid control system are the subject of continuous improvement by the various types of reforms.

Following the example of the practice of the European Union, Serbia has acceded to building a system of state aid control. In Serbia, the implementation of the state aid control system is part of the pre-accession obligations of Serbia in the process of integration into the European Union and began in 2010, with the beginning of the implementation of the Law on State Aid Control (Kerković et al., 2016, p. 160). The law represents a framework for the establishment of the system, and its provisions are elaborated in more detail in the Regulation on Rules for State Aid Granting, initially adopted in 2010 and amended in 2011 (Regulation on Rules for State Aid Granting, 2011).

The authority responsible for the implementation of the state aid control system in Serbia is the Commission for State Aid Control, which also started operating in 2010 (Stanišić, 2016). This body was entrusted with controlling state aid measures until Serbia's prospective accession to the European Union (Jovanić, 2017, p. 137). The Commission consists of five members and is formed by the Government on the proposal of the ministry responsible for finance, the ministry responsible for economy and regional development, the ministry responsible for infrastructure affairs, the ministries responsible for environmental protection and the Commission for Protection of Competition. The representative of the ministry responsible for finance is also the president of the Commission for State Aid Control, and the representative of the Commission for Protection of Competition is the vice president (Law on State Aid Control, p. 2). Such a composition of the Commission for State Aid Control can lead to the question of the provisions of the Law that the Commission must be operatively independent in its work, and suggests that this provision is not essentially significant and introduced to meet the form and demands of international experts which recommend the establishment of an independent monitoring body.

\section{Comparative analysis of state aid granted in the EU and Serbia}

In order to examine the potential effects of established regulations and state aid control system in Serbia, Table 1 gives a comparative overview of the share of state aid granted in gross domestic product (GDP) in the countries of the European Union 
and Serbia in selected years. Data for 2016 are available for countries of the European Union. In Serbia, the last adopted report on the granted state aid is for 2015. The report for the previous year was not adopted in 2017. This breaks the previously established positive practice of publishing reports on state aid granted each year, which is also a legal obligation of the regulatory body.

Table 1: Total state aid as \% of GDP in the EU Member States and Serbia

\begin{tabular}{|c|c|c|c|c|c|c|}
\hline geoltime & 2005 & 2010 & 2015 & 2016 & $\begin{array}{c}\text { Difference } \\
\text { in } 2016 \\
\text { compared to } \\
2005\end{array}$ & $\begin{array}{c}\text { Average } \\
2005- \\
2016\end{array}$ \\
\hline Austria & 0.39 & 0.60 & 0.52 & 0.52 & 0.13 & 0.51 \\
\hline Belgium & 0.32 & 0.59 & 0.48 & 0.57 & 0.25 & 0.49 \\
\hline Bulgaria & 0.11 & 0.05 & 0.73 & 0.61 & 0.50 & 0.37 \\
\hline Croatia & / & / & 0.60 & 0.95 & l & / \\
\hline Cyprus & 1.14 & 0.48 & 0.68 & 0.66 & -0.48 & 0.74 \\
\hline Czech Republic & 0.42 & 0.63 & 1.15 & 1.30 & 0.88 & 0.88 \\
\hline Estonia & 0.13 & 0.10 & 0.95 & 0.82 & 0.69 & 0.50 \\
\hline Finland & 0.40 & 0.46 & 0.75 & 0.76 & 0.37 & 0.59 \\
\hline France & 0.43 & 0.68 & 0.71 & 0.63 & 0.19 & 0.61 \\
\hline Germany & 0.69 & 0.61 & l & l & l & / \\
\hline Greece & 0.32 & 0.77 & 1.24 & 0.36 & 0.04 & 0.67 \\
\hline Hungary & 1.19 & 1.87 & 1.17 & 1.95 & 0.76 & 1.54 \\
\hline Ireland & 0.38 & 0.57 & 0.16 & 0.14 & -0.24 & 0.31 \\
\hline Italy & 0.37 & 0.20 & 0.18 & 0.18 & -0.19 & 0.23 \\
\hline Latvia & 0.60 & 0.83 & 2.20 & 1.46 & 0.86 & 1.27 \\
\hline Lithuania & 0.14 & 0.31 & 0.80 & 0.84 & 0.69 & 0.52 \\
\hline Luxembourg & 0.14 & 0.19 & 0.29 & 0.27 & 0.13 & 0.22 \\
\hline Malta & 2.96 & 1.13 & 0.99 & 0.55 & -2.42 & 1.41 \\
\hline Netherlands & 0.25 & 0.32 & 0.26 & 0.26 & 0.00 & 0.27 \\
\hline Poland & 0.39 & 0.80 & 0.78 & 1.01 & 0.62 & 0.75 \\
\hline Portugal & 0.85 & 0.84 & 0.49 & 0.34 & -0.52 & 0.63 \\
\hline Romania & 0.56 & 0.15 & 0.77 & 0.61 & 0.04 & 0.52 \\
\hline Slovakia & 0.67 & 0.37 & 0.52 & 0.44 & -0.23 & 0.50 \\
\hline Slovenia & 0.44 & 0.80 & 1.09 & 0.74 & 0.30 & 0.77 \\
\hline Spain & 0.52 & 0.40 & 0.21 & 0.20 & -0.31 & 0.33 \\
\hline Sweden & 0.89 & 0.78 & 0.71 & 0.78 & -0.12 & 0.79 \\
\hline United Kingdom & 0.18 & 0.26 & 0.35 & 0.48 & 0.30 & 0.32 \\
\hline EU (28 countries) & 0.45 & 0.50 & 0.63 & 0.67 & 0.22 & 0.56 \\
\hline Serbia & 1.57 & 2.64 & 2.60 & I & 1 & / \\
\hline
\end{tabular}

Source: http://ec.europa.eu/competition/state_aid/studies_reports/studies_reports.html, http://www.kkdp.gov.rs/izvestaji.php 
Based on the data presented in Table 1, it can be concluded that in most countries of the European Union, except for Hungary, Latvia and Malta, the average share of total state aid in GDP in the observed period does not exceed one percent. With its EU membership, Croatia accepted European rules and practice of granting state aid, so the participation of state aid in BDP in 2015 and 2016 is in line with the European average, $0.60 \%$ and $0.95 \%$ respectively. In 2005 , Serbia had a share of $1.57 \%$. In the first year of implementation of the Law on State Aid Control, this share was at a significantly higher level, 2.64\%. Despite the expected tendency of reducing the share of total state aid in GDP with the establishment of a state aid control system, the latest available data indicate relatively high share of total state aid in the GDP of Serbia.

\section{Conclusion}

Eight years after the implementation of the Law on State Aid Control and the establishment of a state aid control system in Serbia, appropriate conclusions on the sustainability of this system can be summarized and systematized appropriate recommendations. The existence of the system and the basic starting assumptions of its functioning is an important step forward. However, it is necessary to work on increasing the institutional and operational independence of the Commission for State Aid Control. It is necessary to redefine its role and responsibilities as an operational, independent body in order to ensure the full implementation of the state aid rules in the following period. The function of the commission must be moved from a formal to an essential, which includes a more rigorous attitude on the justification of state aid.

Further efforts to establish a functional state aid control system may involve adapting the law in a way that will enable the Commission for State Aid Control to be essentially independent and with increased competencies. It is also necessary to activate the discretionary, already legally prescribed right of the commission to order the return of unlawfully granted aid. Further adoption and completion of secondary legislation is a necessary condition for the effective implementation of law and for better coordination between state aid policy and other segments of the economic policy.

In addition to the fact that the share of total state aid granted tin GDP at the level of the European Union is below one percent in the whole observed period, the latest available data indicate the tendency of its further reduction. In Serbia, eight years after the implementation of the Law on State Aid Control, a relatively high share of total state aid in GDP is recorded, without a marked decrease. The relative positive trend in Serbia in relation to the period before the adoption of the law is to increase the share of horizontal state aid, as the most preferred form, in the structure of total aid. Maintaining this trend, with decreasing the share of total state aid in GDP, is challenge for the state aid policy makers in Serbia for the next period. 


\section{References}

Bartniczak, B. (2016). State aid for employment and traning in European Union in years 2008-2013. Annals of'Constantin Brancusi'University of Targu-Jiu. Economy Series, Special Issue, 2, 17-19, 18

Blauberger, M. (2008). From Negative to Positive Integration?, European State Aid Control Through Soft and Hard Law, MPIFG Discussion Paper 08/4.

Blauberger, M. (2011). State Aid control from a political science perspective. Research handbook on European State Aid law. Edward Elgar, Cheltenham, 28-43.

Consolidated versions of the Treaty on the Functioning of the European Union, Official Journal of the European Union (2008/C 115/01)

Jansen, P. (2016). The Interplay between Industrial Policy and State Aid: Natural Combination of Strange Bedfellows. Eur. St. Aid LQ, 4, 575-602.

Jovanić, T. (2017). Competition Authorities as the Pillar of a Competitive Social Market Economy-a Case Study of Institution Building in Serbia. LeXonomica, 9(2), 125142 .

Kassim, H., \& Lyons, B. (2013). The new political economy of EU state aid policy. Journal of Industry, Competition and Trade, 13(1), 1-21.

Kerković, T. M., Stojanović, B., \& Stanišić, T. (2016). Comparative Legal Analysis of Changes in the System of State Aid in Serbia and the Western Balkan CountriesImpact on the Efficiency of the European Integration Process. Teme, 40(1), 155-169.

Kesner-Škreb, M. (2003). Državna potpora poduzećima. Financijska teorija i praksa, 27(1), 157-159.

Krstić, B., \& Stanišić, T. (2013). Analysis of Positive and Negative Effects of State Aid for the Period of the Global Economic Crisis in the EU and Serbia. In B. Krstic (Ed.), Improving the Competitiveness of Enterprises and National Economies Determinants and Solutions (pp. 159-175). Niš: Ekonomski fakultet, Univerzitet u Nišu, Krakov: Andrzej Frycz Modrzewski Krakow University.

Podsiado, P. (2016). State aid and the functioning of the Single European Market-the crisis perspective. Ekonomia i Prawo, 15(3), 385-399.

Stanišić, T. (2016). Analiza državne pomoći u Srbiji, zemljama u regionu i Evropskoj uniji. U B. Krstić (Ed.) Ključni aspekti unapređenja konkurentnosti Republike Srbije, monografska studija (str. 195-234), Niš: Ekonomski fakultet u Nišu.

Stojanović, B. (2003). Tržište Evropske unije - konkurencija i trgovinska politika. Niš: Ekonomski fakultet u Nišu.

Stojanović, B., \& Stanišić, T. (2014). Državna pomoć i realni sektor ekonomije u poslednjoj svetskoj ekonomskoj krizi. Ekonomika, 60(3), 87-97.

Stojanović, B., \& Stanišić, T. (2015). Sectoral state aid in the European Union and the Western Balkan countries, Ekonomske teme, 53(3): 335-347.

Stojanović, B., Stanišić, T., \& Radivojević, V. (2013). State Aid Control: Theoretical Aspects and Empirical Evidences. Facta Universitatis: Economics and Organization, $10(2), 165-177$. 
Stojanović, B., Stanišić, T., \& Radivojević, V. (2014). Efekti institucionalizacije državne pomoći u Republici Srbiji. Institucioanlne promene kao determinanta privrednog razvoja Srbije, Kragujevac: Ekonomski fakultet, str. 85 - 104.

Tasan-Kok, T., Groetelaers, D. A., Haffner, M. E., Van Der Heijden, H. M., \& Korthals Altes, W. K. (2013). Providing cheap land for social housing: Breaching the state aid regulations of the single European market?. Regional studies, 47(4), 628-642.

Uredba o pravilima za dodelu državne pomoći, Službeni glasnik RS, br. 13/2010, 100/2011

Zakon o kontroli državne pomoći (2009), Službeni glasnik RS, br. 51. 